\title{
Kebijakan Hukum Pidana Terkait Perdagangan Pengaruh (Trading In Influence) Sebagai Tindak Pidana Korupsi
}

\author{
Moh. Akil Rumaday \\ Magister Hukum Fakultas Hukum Universitas Islam Indonesia Yogyakarta Indonesia \\ Jln. Cik Di Tiro, No. 1, Yogyakarta 55223 Indonesia \\ akiljustice7@gmail.com
}

\begin{abstract}
This study aims to determine the regulation of the crime of trading in influence in the United Nations Convention against Corruption (UNCAC) 2003 and to consider the decision of the panel of judges in adjudicating cases of trading in influence as a criminal act of corruption in Indonesia. This is a normative legal research that uses statutory, conceptual, and case approaches. The results of this study concluded that trading in influence as a type of corruption crime regulated in Article 18 of UNCAC consists of trading in influence actively and passively. In the practice of law enforcement against corruption, the Panel of Judges in their consideration has implemented UNCAC provisions related to trading in influence in adjudicating the Riau-1 Steam Power Plant (PLTU) case and the case of sale and purchase of certain positions at the Ministry of Religion. This shows that trading in influence as a criminal act of corruption has occurred in Indonesia. Therefore, as a country that has ratified UNCAC, criminal law policies related to eradicating corruption in Indonesia need to adopt the provisions of Article 18 of UNCAC to increase the effectiveness of law enforcement on corruption in Indonesia.
\end{abstract}

Key Words: Corruption crime; criminal law policy; trading in influence

\begin{abstract}
Abstrak
Penelitian ini bertujuan untuk mengetahui pengaturan kejahatan perdagangan pengaruh (trading in influence) dalam United Nations Convention against Corruption (UNCAC) 2003 dan pertimbangan putusan majelis hakim dalam mengadili perkara perdagangan pengaruh (trading influence) sebagai tindak pidana korupsi di Indonesia. Jenis penelitian ini adalah hukum normatif yang menggunakan metode pendekatan perundang-undangan, pendekatan konseptual, dan pendekatan kasus. Hasil penelitian ini menyimpulkan bahwa perdagangan pengaruh (trading in influence) sebagai salah satu jenis tindak pidana korupsi yang diatur dalam Pasal 18 UNCAC terdiri atas memperdagangkan pengaruh secara aktif dan pasif. Di dalam praktik penegakan hukum tindak pidana korupsi, Majelis Hakim dalam pertimbangannya sudah mengimplementasikan ketentuan UNCAC terkait perdagangan pengaruh dalam mengadili kasus Proyek Pembangkit Listrik Tenaga Uap (PLTU) Riau-1 dan kasus jual beli jabatan dalam seleksi jabatan di Kementrian Agama. Hal ini menunjukkan bahwa trading in influence sebagai tindak pidana korupsi sudah terjadi di Indonesia. Oleh karena itu, sebagai negara yang telah meratifikasi UNCAC, kebijakan hukum pidana terkait pemberantasan tindak pidana korupsi di Indonesia perlu mengadopsi ketentuan Pasal 18 UNCAC untuk meningkatkan efektivitas penegakan hukum tindak pidana korupsi di Indonesia.
\end{abstract}

Kata-kata Kunci: Kebijakan hukum pidana; perdagangan pengaruh; tindak pidana korupsi 


\section{Pendahuluan}

Penyusunan Undang-Undang Nomor 31 Tahun 1999 dan Undang-Undang Nomor 20 Tahun 2001 tentang Perubahan atas Undang-Undang Nomor 31 Tahun 1999 tentang Pemberantasan Tindak Pidana Korupsi diharapkan dapat menjadi instrumen pemberantasan tindak pidana korupsi yang efektif. Undang-undang ini merupakan respons terhadap perkembangan tindak pidana korupsi yang terjadi namun dalam perkembangannya masih terdapat permasalahn yaitu dari aspek substansi, salah satunya yaitu tidak adanya pengaturan tentang perdagangan pengaruh (trading in influence).

Penanganan perkara tindak pidana korupsi yang dilakukan oleh Komisi Pemberantasan Korupsi dalam kasus-kasus yang memiliki relevansi dengan perdagangan pengaruh (trading in influence) diantaranya yaitu, pertama, kasus yang melibatkan terdakwa Idrus Marham. Putusan perkara tersebut menyatakan bahwa terdakwa bersama-sama dengan Eni Maulani Saragih selaku pegawai negeri atau penyelenggara negara yaitu anggota Komisi VII Dewan Perwakilan Rakyat Republik Indonesia (DPR-RI) periode 2014 sampai dengan 2019, sekitar pada 18 Desember 2017 dan 08 Juni 2018 telah melakukan atau turut serta melakukan beberapa perbuatan yang dipandang sebagai perbuatan berlanjut, menerima hadiah atau janji yaitu menerima hadiah berupa uang secara bertahap yang seluruhnya berjumlah Rp. 2.250.000.000,00 dari Johanes Budisutrisno Kotjo selaku pemegang saham Blackgold Natural Resources, Ltd (BNR, Ltd). Di dalam putusan perkara tersebut dinyatakan bahwa terdakwa seharusnya mengetahui atau patut menduga bahwa hadiah berupa uang tersebut diberikan agar Terdakwa dan Eni Maulani Saragih membantu Johanes Budisutrisno Kotjo untuk mendapatkan proyek Independent Power Producer (IPP) Pembangkit Listrik Tenaga Uap Mulut Tambang Riau-1 (Pltu Mt Riau-1).

Kedua, kasus yang melibatkan terdakwa Muchammad Romahurmuziy selaku Anggota Dewan Perwakilan Rakyat Republik Indonesia (DPR RI) periode 2014-2019 yang sekaligus selaku Ketua Umum Partai Persatuan Pembangunan (PPP). Di dalam putusan tersebut disebutkan bahwa terdakwa bersama-sama dengan Lukman Hakim Saifuddin selaku Menteri Agama Republik Indonesia periode 2014-2019, pada waktu antara 6 Januari 2019 sampai dengan 09 Maret 2019 melakukan atau turut serta melakukan beberapa perbuatan yang dipandang sebagai perbuatan berlanjut, yaitu menerima hadiah yaitu menerima uang seluruhnya sejumlah Rp. 325.000.000,00 dari Haris Hasanudin. Terdakwa seharusnya mengetahui atau patut menduga bahwa uang tersebut diberikan karena terdakwa telah melakukan intervensi baik langsung maupun tidak langsung terhadap proses pengangkatan Haris Hasanudin sebagai Kepala Kantor Wilayah (Kanwil) Kementerian Agama Provinsi Jawa Timur. 
Tindak pidana korupsi berupa pemanfaatan pengaruh (trading in influence) diatur secara tegas dalam Pasal 18 huruf (a) dan Pasal 18 huruf (b) The United Nations Convention Against Corruption (UNCAC). ${ }^{1}$ UNCAC adalah Konvensi Perserikatan Bangsa Bangsa Antikorupsi yang merupakan instrumen hukum internasional yang bertujuan mengatasi masalah korupsi pada tingkat global. UNCAC memperkenalkan seperangkat standar, aturan dan upaya-upaya yang dapat diimplementasikan oleh negara-negara di dunia untuk memperkuat kerangka hukumnya dalam memberantas korupsi secara efektif. ${ }^{2}$ Konsensi tersebut diadopsi oleh Sidang Umum PBB pada 31 Oktober 2003 dan telah diratifikasi oleh 183 negara di dunia, termasuk Indonesia yang meratifikasi UNCAC melalui Undang-Undang Nomor 7 Tahun 2006. Dengan meratifikasi konvensi ini, artinya Indonesia wajib melaksanakan pasal-pasal yang ada di dalamnya. ${ }^{3}$

Pasca Pemerintah Indonesia meratifikasi UNCAC tersebut hingga kini, penegakan hukum pemberantasan tindak pidana korupsi belumlah optimal, hal tersebut dikarenakan pola korupsi dan pelaku korupsi mayoritas berafiliasi dengan cabang kekuasaan dan memegang jabatan penting. Dalam merespons perkembangan korupsi yang terjadi, justru upaya dan tindakan sebaliknya dilakukan negara (eksekutif dan legislatif) dengan melakukan revisi terhadap Undang-Undang Nomor 30 Tahun 2002 dengan memberlakukan dan menambah Undang-Undang Nomor 19 Tahun 2019 tentang Komisi Pemberantasan Korupsi.

Laode M Syarif selaku Wakil Ketua Komisi Pemberantasan Korupsi (KPK) periode 2015-2019 mempertanyakan revisi yang dilakukan Pemerintah dan DPR, menurutnya perlu dikaji apakah Indonesia telah comply (patuh) sebagai pihak yang meratifikasi UNCAC mengingat undang-undang tindak pidana korupsi yang belum mengakomodir beberapa ketentuan UNCAC, salah satunya yaitu mengenai perdagangan pengaruh (trading in influence). ${ }^{4}$ Artinya, justru undangundang pemberantasan tindak pidana korupsi yang seharusnya direvisi dengan memuat beberapa perbuatan baik yang bersifat mandatory maupun non-mandatory yang belum diatur dalam UU Pemberantasan Tindak Pidana Korupsi.

Pengaturan perdagangan pengaruh (trading in influence) didalam UNCAC tersebut termasuk dalam non-mandatory offences namun pemaparan kasus-kasus di atas menunjukkan bahwa praktek perdagangan pengaruh sebagai tindak pidana

\footnotetext{
${ }^{1}$ Kristian dan Yopi Gunawan, Tindak Pidana Korupsi Kajian terbadap Harmonisasi antara Hukum Nasional dan The United Nations Convention Againts Corruption (UNCAC), Cetakan Kesatu, PT Refika Aditama, Bandung, 2015, hlm. 137.

2 Tim Penyusun Laporan Tahunan KPK 2017, Laporan Tahunan 2017 Demi Indonesia Untuk. Indonesia, Komisi Pemberantasan Korupsi, Jakarta, 2018, hlm. 46.

${ }^{3}$ Ibid.

4 Dylan Aprialdo Rachman, https://nasional.kompas.com/read/2019/12/10/15041921/akibat-revisi-uukpk-indonesia-dinilai-tak-patuh-dengan-konvensi-antikorupsi?page=1, "Akibat Revisi UU KPK, Indonesia Dinilai Tak Patuh dengan Konvensi Antikorupsi PBB”, Akses 29 Desember 2019, pukul 22.45 Wib.
} 
korupsi sudah terjadi di Indonesia. Oleh karena itu penelitian ini akan mengkaji secara komprehensif terkait pengaturan perdagangan pengaruh (trading in influence) dalam UNCAC dan akan menganalisis pertimbangan hakim dalam mengadili perkara perdagangan pengaruh (trading influence) sebagai tindak pidana korupsi.

\section{Rumusan Masalah}

Berdasarkan latar belakang masalah di atas, rumusan masalah penelitian ini adalah, pertama, bagaimana pengaturan kejahatan perdagangan pengaruh (trading in influence) dalam United Nations Convention against Corruption (UNCAC)? Kedua, apa pertimbangan majelis hakim dalam kasus mengadili perkara perdagangan pengaruh (trading influence) sebagai tindak pidana korupsi?

\section{Tujuan Penelitian}

Adapun tujuan dari penelitian ini ialah pertama, untuk mengetahui pengaturan kejahatan perdagangan pengaruh (trading in influence) dalam United Nations Convention against Corruption (UNCAC). Kedua, untuk mengetahui pertimbangan putusan majelis hakim dalam mengadili perkara perdagangan pengaruh (trading influence) sebagai tindak pidana korupsi.

\section{Metode Penelitian}

Penelitian ini adalah penelitian hukum normatif yang menggunakan metode pendekatan perundang-undangan, pendekatan konseptual, dan pendekatan kasus. Data penelitian ini berupa bahan hukum primer, sekunder, dan tersier, yang dikumpulkan denagn cara studi dokumen dan studi kepustakaan. Data penelitian tersebut dianalisis menggunakan metode deskriptif-kualitatif.

\section{Hasil Penelitian dan Pembahasan}

Pengaturan Perdagangan Pengaruh (Trading in Influence) dalam United Nations Convention Against Corruption (UNCAC)

Perdagangan Pengaruh (Trading in Influence) diatur dalam Pasal 18 United Nations Convention Against Corruption 2003 (UNCAC) $^{5}$ yang menyatakan bahwa

${ }^{5}$ Each State Party shall consider adopting such legislative and other measures as may be necessary to establish as criminal offences, when committed intentionally:

a. The promise, offering or giving to a public official or any other person, directly or indirectly, of an undue advantage in order that the public official or the person abuse his or her real or supposed influence with a view to obtaining from an administration or public authority of the State Party an undue advantage for the original instigator of the act or for any other person;

b. The solicitation or acceptance by a public official or any other person, directly or indirectly, of an undue advantage for himself or herself or for another person in order that the public official or the person abuse his or her real or supposed influence with a view to obtaining from an administration or public authority of the State Party an undue advantage. 
setiap negara pihak wajib mempertimbangkan untuk mengambil tindakan legislatif dan lainnya yang diperlukan untuk ditetapkan sebagai tindak pidana, jika dilakukan dengan sengaja dengan cara berikut, yaitu pertama, janji, penawaran, atau pemberian manfaat kepada pejabat publik atau orang lain, secara langsung atau tidak langsung, dari keuntungan yang tidak semestinya agar pejabat publik atau orang tersebut menyalahgunakan pengaruhnya yang nyata atau seharusnya dengan maksud untuk memperoleh dari lembaga pemerintah atau lembaga publik negara pihak untuk suatu keuntungan yang tidak semestinya bagi penghasut asli tindakan tersebut atau untuk orang lain. ${ }^{6}$ Kedua, Permintaan atau penerimaan manfaat oleh pejabat publik atau orang lain, secara langsung atau tidak langsung, dari keuntungan yang tidak semestinya untuk dirinya sendiri atau untuk orang lain dengan tujuan agar pejabat publik atau orang tersebut menyalahgunakan pengaruhnya yang nyata atau seharusnya dengan maksud untuk mendapatkan dari lembaga pemerintah atau lembaga publik negara pihak suatu keuntungan yang tidak semestinya. ${ }^{7}$

Ketentuan Pasal 18 poin a UNCAC tersebut menunjukkan bahwa unsurunsur perdagangan pengaruh sebagai tindak pidana korupsi yaitu pertama, dengan sengaja, kedua, janji, penawaran, atau pemberian manfaat, ketiga, kepada pejabat publik atau orang lain, keempat secara langsung atau tidak langsung, kelima, dari keuntungan yang tidak semestinya, keenam, agar pejabat publik atau orang tersebut menyalahgunakan pengaruhnya yang nyata atau seharusnya dengan maksud untuk memperoleh dari lembaga pemerintah atau lembaga publik negara pihak untuk suatu keuntungan yang tidak semestinya bagi penghasut asli tindakan tersebut atau untuk orang lain.

Unsur-unsur perdagangan pengaruh sebagai tindak pidana korupsi berdasarkan ketentuan Pasal 18 poin b UNCAC adalah pertama, dengan sengaja, kedua, permintaan atau penerimaan manfaat, ketiga, oleh pejabat publik atau orang lain, keeempat secara langsung atau tidak langsung, kelima, dari keuntungan yang tidak semestinya, keenam, untuk dirinya sendiri atau untuk orang lain dengan tujuan agar pejabat publik atau orang tersebut menyalahgunakan pengaruhnya yang nyata atau seharusnya dengan maksud untuk mendapatkan dari lembaga pemerintah atau lembaga publik negara pihak suatu keuntungan yang tidak semestinya.

Rumusan Pasal 18 UNCAC dan unsur-unsurnya di atas menunjukkan bahwa perbuatan perdagangan pengaruh dibagi menjadi dua yaitu

6 Donal Fariz, et.al., Kajian Implementasi Aturan Trading in Influence dalam Hukum Nasional, Indonesia Corruption Watch, 2014

${ }^{7}$ Ibid 
memperdagangkan pengaruh secara aktif, sebagaimana diatur dalam poin a, dan memperdagangkan pengaruh secara pasif, yang diatur dalam poin b. Selain itu, subyek hukum yang dapat dimintakan tanggungjawab dari kedua rumusan yang terdapat dalam pasal tersebut di atas adalah setiap orang dan pejabat publik. Unsur subjektif kedua rumusan pasal tersebut ialah setiap orang yang melakukan perbuatan dengan sengaja yang dituju (penerima suap) melakukan atau tidak melakukan kewajiban yang sepatutnya dilakukan. Sementara kaitannya dengan unsur objektifnya ialah janji, penawaran, pemberian manfaat, permintaan atau penerimaan manfaat dari keuntungan yang tidak semestinya, kepada pejabat publik atau orang lain untuk dirinya sendiri atau untuk orang lain dengan tujuan agar pejabat publik atau orang tersebut menyalahgunakan pengaruhnya yang nyata atau seharusnya dengan maksud untuk mendapatkan dari lembaga pemerintah atau lembaga publik negara pihak suatu keuntungan yang tidak semestinya.

\section{Analisis Pertimbangan Majelis Hakim dalam Mengadili Kejahatan Perdagangan Pengaruh (Trading in Influence)}

Ketentuan perdagangan pengaruh (trading in influence), sebagaimana telah dijelaskan sebelumnya, belum diatur secara eksplisit dalam hukum pidana Indonesia. Akan tetapi, beberapa kasus tindak pidana korupsi yang telah diputus oleh pengadilan mengindikasikan praktek perdagangan pengaruh sebagai bentuk tindak pidana korupsi telah terjadi di Indonesia. Salah satunya yaitu kasus Proyek Pembangkit Listrik Tenaga Uap (PLTU) Riau-1 yang telah diputus dalam Putusan Nomor $3681 \mathrm{~K} /$ Pid.Sus/2019. Majelis Hakim Pengadilan Tingkat Pertama yang mengadili perkara tersebut menyatakan terdakwa telah terbukti secara sah dan meyakinkan bersalah melakukan tindak pidana korupsi yang dilakukan secara bersama-sama sebagaimana dalam dakwaan kedua, yaitu melanggar Pasal 11 Undang-Undang Pemberantasan Tindak Pidana Korupsi (UUPTPK). Berdasarkan keterangan saksi-saksi, keterangan ahli, keterangan terdakwa, pemeriksaan barang bukti, alat bukti surat, serta fakta hukum dalam perkara a quo, diketahui bahwa putusan majelis hakim yang didasarkan pada dakwaan alternatif kedua merupakan hal yang tepat dan sesuai. Hal ini disebabkan penjatuhan putusan oleh pengadilan tingkat pertama tersebut telah berdasar pada kesimpulan pendapat majelis hakim yang bersifat yuridis dan berdasar pada fakta hukum persidangan

Di dalam mengadili perkara a quo, majelis Hakim pada Pengadilan tingkat pertama, tingkat banding, dan majelis Hakim pada Mahkamah Agung dalam putusannya menyatakan bahwa terdakwa telah terbukti secara sah dan meyakinkan bersalah melakukan tindak pidana korupsi, namun terdapat 
perbedaan vonis pidana yang dijatuhkan yaitu lamanya pidana penjara dan besarnya pidana denda. Perbedaan tersebut salah satunya disebabkan perbedaan dasar dakwaan yang digunakan oleh pengadilan tingkat banding dengan pengadilan tingkat pertama dan tingkat kasasi. Majelis hakim di tingkat kasasi memiliki pendapat yang sama dengan majelis hakim pengadilan tingkat pertama. Akan tetapi, Pengadilan tingkat banding menyatakan terdakwa terbukti secara sah melakukan tindak pidana korupsi sebagaimana diatur dalam Pasal 12 huruf a UUPTPK dimana penggunaan pasal tersebut kurang tepat.

Pertimbangan Majelis hakim tingkat kasasi yang mengadili perkara tersebut adalah pertama, pertimbangan hukum putusan judex facti Pengadilan Tinggi a quo tidak dapat dibenarkan menurut hukum karena ternyata merupakan kesimpulan pendapat yang bersifat asumsi tidak berdasarkan fakta hukum persidangan. Hubungan hukum perbuatan antara saksi Eni Maulani Saragih dan perbuatan Terdakwa Idrus Marham adalah dalam hubungan untuk memenuhi permintaan saksi Eni Maulani Saragih untuk menghubungi dan mengajak untuk bertemu serta meminta tolong kepada Johanes Budisutrisno Kotjo yang sebelumnya sudah diperankan oleh Eni Saragih adanya janji pemberian fee antara Johanes Budisutrisno Kotjo dan Eni Saragih dalam hubungan kedudukan Eni Saragih sebagai anggota Komisi VIII DPR-RI yang bertugas membidangi Energi, Riset dan Teknologi dan selaku Bendahara Munas Golkar yang akan dikawal dan diberikan kepada Johanes Budisutrisno Kotjo untuk melaksanakan Proyek PLTU-Riau 1 tersebut. ${ }^{8}$

Kedua, Majelis Hakim menyatakan bahwa perbuatan yang diperankan Terdakwa Idrus Marham tersebut yang dimohonkan oleh saksi Eni Maulani Saragih kepada terdakwa adalah merupakan perbuatan menggunakan pengaruh kekuasaan dalam kedudukan terdakwa Idrus Marham sebagai Plt. Ketua Umum Golkar untuk mempengaruhi saksi Johanes Budisutrisno Kotjo agar memberi hadiah atau janji dari Johanes Budisutrisno Kotjo kepada saksi Eni Muliani Saragih, karena itu perbuatan Terdakwa Idrus Marham menurut judex facti Pengadilan Tinggi bahwa Terdakwa ikut serta meminta hadiah atau janji tidak dapat dibenarkan karena tidak berhubungan dengan jabatan atau kekuasaan/kewenangan terdakwa selaku Plt. Ketua Umum Golkar dengan pemberian janji/hadiah Johanes Budisutrisno Kotjo sehingga terdakwa tidak dapat dikualifikasi melakukan perbuatan yang mempunyai peran aktif dalam tindak pidana suap sebab tidak ada hubungan kekuasaan/kewenangan melakukan sesuatu dalam jabatannya yang bertentangan dengan kewajibannya dalam hubungan pemberian fee proyek PLTU Riau-1 tersebut.

\footnotetext{
8 Putusan Nomor 3681 K/Pid.Sus/2019, hlm. 82-83.
} 
Ketiga, Terdakwa Idrus Marham dalam kedudukannya sebagai Plt. Ketua Umum Golkar dapat dipersalahkan melakukan perbuatan dengan menggunakan pengaruh kekuasaannya untuk kepentingan Eni Maulani Saragih, telah menerima hadiah atau janji berupa sejumlah uang sebagai hadiah atau janji untuk mengawal dan memberikan proyek PLTU Riau-1 kepada Johanes Budisutrisno Kotjo yang sebelumnya hadiah atau janji tersebut sudah disepakati bersama antara Eni Maulani Saragih dan Johanes Budisutrisno Kotjo untuk kepentingan pelaksanaan Munaslub Golkar dan untuk kepentingan pribadi Eni Maulani Saragih dalam pencalonan suaminya sebagai calon Bupati dalam Pilkada Kabupaten Temanggung. ${ }^{9}$

Keempat, putusan judex facti Pengadilan Tindak Pidana Korupsi pada Pengadilan Tinggi telah keliru dan kurang tepat dalam menerapkan hukum terhadap perbuatan Terdakwa tersebut, melainkan lebih tepat diterapkan putusan judex facti Pengadilan Tindak Pidana Korupsi pada Pengadilan Negeri Jakarta Pusat atas perbuatan Terdakwa Idrus Marham yang telah memenuhi semua unsur delik Pasal 11 Undang-Undang Nomor 31 Tahun 1999 juncto Undang-Undang Nomor 20 Tahun 2001 juncto Pasal 55 ayat (1) ke-1 KUHP juncto Pasal 64 ayat (1) KUHP dalam Surat Dakwaan Kedua sebagaimana telah dibuktikan dalam putusan judex facti Pengadilan Tindak Pidana Korupsi pada Pengadilan Negeri Jakarta Pusat, meskipun penjatuhan pidana penjara terhadap Terdakwa Idrus Marham masih perlu diperbaiki mengenai lamanya pidana penjara dengan pertimbangan Terdakwa menggunakan pengaruh kekuasaannya ikut serta secara tidak langsung menerima hadiah atau janji yang ada hubungannya dengan kepentingan Terdakwa untuk mencalonkan diri Ketua Umum Golkar dalam Munaslub Partai Golkar yang direncanakan. ${ }^{10}$

Berdasarkan pendapat majelis Hakim pada Mahkamah Agung Judex Juris ${ }^{11}$ tersebut di atas, dapat diketahui dua hal, yaitu pertama, semakin jelas dan terang bahwa ternyata majelis Hakim Judex Factie ${ }^{12}$ Pengadilan Tinggi dalam penjatuhan Putusan tidak mampu menguraikan ketepatan kesalahan Terdakwa sehingga dapat dikualifikasi majelis Hakim mengalami kesesatan berfikir dan kekeliruan yang nyata. Kedua, bahwa pendapat tersebut diatas menunjukkan bahwa terdakwa melakukan perbuatan perdagangan pengaruh trading in influence dalam perkara a quo.

9 Ibid

10 Ibid

11 Judex Yuris merupakan peradilan pada tingkat mahkamah agung yang mana para majelis hakim memeriksa, mengadili, dan menguji terhadap putusan yang telah dijatuhkan oleh pengadilan pada semua jenjang dibawahnya mengenai bagaimana penerapan hukum yang telah dilakukan oleh pengadilan disemua lingkungan yang berada dibawahnya.

${ }^{12}$ Judex Factie ialah pengadilan pada tingkat pertama (pengadilan negeri) dan pengadilan pada tingkat banding (pengadilan tinggi) yang mana para hakim memeriksa, mengadili dan memutus dan menjatuhkan putusannya berdasarkan fakta-fakta hukum dalam persidangan. 
Perdagangan pengaruh juga terjadi pada kasus jual beli jabatan dalam seleksi jabatan di Kementrian Agama yang telah diadili melalui Putusan Nomor: 87/Pid.Sus-TPK/2019/PN.Jkt.Pst. Majelis Hakim yang mengadili perkara a quo menyatakan terdakwa telah terbukti secara sah dan meyakinkan bersalah melakukan tindak pidana korupsi secara bersama-sama dan berlanjut sebagaiman diatur dalam Pasal 11 UUPTPK. Berkaitan dengan perbuatan perdagangan pengaruh dalam kasus ini, pertimbangan majelis hakim dalam putusan tersebut menyatakan bahwa terdakwa selaku Anggota DPR-RI sekaligus selaku Ketua Partai Persatuan Pembangunan (PPP) melakukan intervensi kepada saksi Lukman Hakim Saifuddin selaku Menteri Agama RI dalam proses pemilihan seleksi Pejabat Tinggi Pratama di lingkungan Kementrian Agama RI, serta adanya penerimaan sejumlah uang oleh Terdakwa dari dari Haris Hasanuddin. ${ }^{13}$

Pertimbangan majelis hakim di atas menunjukkan telah terjadinya perbuatan perdagangan pengaruh (trading in influence) sebagai bentuk tindak pidana korupsi yang dilakukan oleh terdakwa terhadap Haris Hasanuddin. Hal ini terlihat dari pertimbangan majelis Hakim yang menyatakan bahwa Terdakwa telah menerima hadiah berupa uang dari saksi Haris Hasanuddin sebanyak dua tahap yaitu pertama pada 06 Januari 2019 sebesar Rp. 5.000.000,00 walaupun diingkari oleh Terdakwa bahwa ia tidak pernah menerima uang tersebut dari saksi Haris Hasanudin dan pada 06 Februari 2019 sebesar Rp. 250.000.000,00, sebagai kompensasi Terdakwa yang membantu pengangkatan saksi Haris Hasanuddin sebagai Kepala Kantor Wilayah Kementrian Agama Provinsi Jawa Timur.

Menanggapi putusan-putusan tersebut, dengan mengutip apa yang disampaikan oleh Artidjo Alkostar, bahwa setiap putusan harus dipertanggungjawabkan kepada, (a) kepada kebenaran ilmu, (b) kepada institusinya, (c) harus dipertanggungjawabkan kepada public, (d) harus dipertanggungjawabkan kepada hati nuraninya, dan (d) harus dipertanggungjawabkan kepada YME (Transenden). ${ }^{14}$ Pandangan di atas tentu begitu komprehensif, fundamental, rasional, logis, mengandung spiritualitas dan sangat ideal ketika di implementasikan dalam setiap penegakan hukum. Proses penegakan hukum, khususnya yang dilakukan oleh hakim, tidak saja memandang hukum dalam menafsirkan pasal-pasal dalam undang-undang saja, akan tetapi alangkah lebih logis dan sesuai dengan nila-nilai tersebut, haruslah terpatri dalam setiap jiwa dan pikiran setiap hakim yang memutus perkara yang ditugaskan kepadanya. Dalam hal ini kasus yang telah dilakukan oleh Terdakwa yakni perbuatan perdagangan pengaruh trading in influence.

13 Putusan Nomor: 87/Pid.Sus-TPK/2019/PN.Jkt.Pst, hlm 515-516.

14 Artidjo Alkostar, "Hukum Pidana dan Hak Asasi Manusia", penyampaian langsung dalam Kuliah Kelas Pidana pada Program Magister Hukum, Fakultas Hukum Universitas Islam Indonesia Yogyakarta, 04 Mei 2019. 
Pemaparan di atas menguatkan urgensi pengaturan trading in influence dalam undang-undang pemberantasan tindak pidana korupsi. Indonesia sebagai anggota PBB juga telah meratifikasi United Nations Convention against Corruption 2003 (UNCAC) dimana Pasal 18 konvensi tersebut mengatur tentang trading in influence. Ratifikasi tersebut merupakan salah satu pintu masuk hukum internasional ke hukum nasional. ${ }^{15}$ Selain itu, Praktek perdagangan pengaruh sebagai bentuk tindak pidana korupsi telah terjadi di Indonesia dengan dibuktikan oleh pertimbangan hakim dalam putusan-putusan di atas. Oleh karena itu, kebijakan hukum pidana terkait pemberantasan tindak pidana korupsi perlu mengadopsi ketentuan Pasal 18 UNCAC guna meningkatkan efektivitas penegakan hukum tindak pidana korupsi di Indonesia.

\section{Penutup}

Berdasarkan pemaparan hasil penelitian di atas, dapat disimpulkan bahwa, pertama, perdagangan pengaruh (trading in influence) sebagai salah satu jenis tindak pidana korupsi belum diatur dalam peraturan perundang-undangan pemberantasan tindak pidana korupsi di Indonesia namun sudah diatur dalam Pasal 18 United Nations Convention Against Corruption 2003 (UNCAC) yang telah diratifikasi oleh Indonesia. Tindak pidana perdagangan pengaruh yang diatur dalam Pasal 18 tersebut dibagi menjadi dua yaitu memperdagangkan pengaruh secara aktif dan memperdagangkan pengaruh secara pasif.

Kedua, di dalam praktik penegakan hukum tindak pidana korupsi, Majelis Hakim dalam pertimbangannya sudah mengimplementasikan ketentuan UNCAC terkait perdagangan pengaruh dalam mengadili kasus Proyek Pembangkit Listrik Tenaga Uap (PLTU) Riau-1 dan kasus jual beli jabatan dalam seleksi jabatan di Kementrian Agama. Hal ini menunjukkan bahwa trading in influence sebagai tindak pidana korupsi sudah terjadi di Indonesia sehingga kebijakan hukum pidana terkait pemberantasan tindak pidana korupsi perlu mengadopsi ketentuan Pasal 18 UNCAC guna mengingkatkan efektivitas penegakan hukum tindak pidana korupsi di Indonesia.

\section{Daftar Pustaka}

\section{Buku}

Gunawan, Yopi dan Kristian, Tindak Pidana Korupsi Kajian terhadap Harmonisasi antara Hukum Nasional dan The United Nations Convention Againts Corruption (UNCAC), Cetakan Kesatu, PT Refika Aditama, Bandung, 2015.

15 Artidjo Alkostar, "Hukum Pidana dan Hak Asasi Manusia”, penyampaian langsung dalam Kuliah Kelas Pidana pada Program Magister Hukum, Fakultas Hukum Universitas Islam Indonesia Yogyakarta, 11 Mei 2019 
Mulyadi, Lilik, Hukum Acara Pidana Suatu Tinjauan Khusus Terhadap Surat Dakwaan, Eksepsi dan Putusan Peradilan, Cetakan ke I, PT. Citra Aditya Bakti, Bandung, 1996.

Nasution, Ajarotni et. al., Naskah Akademik Rancangan Undang-undang Pemberantasan Tindak Pidana Korupsi, Badan Pembinaan Hukum Nasional Departemen Hukum dan Hak Asasi Manusia RI, Jakarta, 2009.

Soesilo, R., dan M. Karjadi Kitab Undang-undang Hukum Acara Pidana Dengan Penjelasan Resmi dan Komentar, Politeia, Bogor, 1997

Tim Penyusun Laporan Tahunan KPK 2017, Laporan Tahunan 2017 Demi Indonesia Untuk Indonesia, Komisis Pemberantasan Korupsi, Jakarta, 2018.

\section{Internet}

Dylan Aprialdo Rachman, https://nasional.kompas.com/read/2019/12/10/ 15041921/akibat-revisi-uu-kpk-indonesia-dinilai-tak-patuh-dengankonvensi-antikorupsi?page=1, "Akibat Revisi UU KPK, Indonesia Dinilai Tak Patuh dengan Konvensi Antikorupsi PBB", Akses 29 Desember 2019, pukul $22.45 \mathrm{Wib}$.

\section{Kuliah Langsung}

Alkostar, Artidjo, Hukum Pidana dan Hak Asasi Manusia, penyampaian langsung dalam Kuliah Kelas Pidana pada Program Magister (S-2), Fakultas Hukum UII, Yogyakarta, 11 Mei 2019.

\section{Putusan Pengadilan}

Putusan Pengadilan Negeri Jakarta Pusat bernomor 9/PID.SUSTPK/2019/PN.JKT.PST.

Putusan Pengadilan Tindak Pidana Korupsi pada Pengadilan Tinggi DKI Jakarta yang bernomor 16/PID.SUS-TPK/2019/PT.DKI.

Putusan Kasasi Mahkamah Agung Nomor 3681 K/Pid.Sus/2019.

Putusan Pengadilan Negeri Jakarta Pusat bernomor 87/Pid.SusTPK/2019/PN.Jkt.Pst

Putusan pada Pengadilan Tindak Pidana Korupsi pada Pengadilan Tinggi DKI Jakarta yang bernomor 9/Pid.Sus-TPK/2020/PT.DKI.

\section{Peraturan Perundang-Undangan}

Undang-undang Republik Indonesia Nomor 31 Tahun 1999 tentang Pemberantasan Tindak Pidana Korupsi, Lembaran Negara Republik Indonesia Tahun 1999 Nomor 140, dan Tambahan Lembaran Negara Republik Indonesia Nomor 3874.

Undang-Undang RI Nomor 20 Tahun 2001 tentang Perubahan Atas Undangundang Nomor 31 Tahun 1999 tentang Pemberantasan Tindak Pidana Korupsi, Lembaran Negara RI Tahun 2001 Nomor 134, dan Tambahan Lembaran Negara RI Nomor 4150.

United Nations Convention Against Corruption (UNCAC), 2003. 